\title{
PENGARUH MODEL PEMBELAJARAN DAN MINAT BELAJAR TERHADAP HASIL BELAJAR STATISTIK
}

\author{
Budi Prasetya \\ Hartati Muchtar \\ Zulfiati Syahrial
}

\begin{abstract}
The purpose of this study was to examine the effect of learning models and learning interests on statistical learning outcomes. This research was conducted on students of Mechanical Engineering Study Program, Jakarta State University in 2017. The sample consisted of 64 students from 2 (two) classes based on measurement of learning interest. This study uses an experimental method with the design of $2 \times 2$ Treatment by Level. Data analysis using two-way ANAVA followed by the Tukey test. The results showed that: (1) the learning outcomes of the students who are learn by the learning model of the website is higher than the outcomes of student learning learn by direct learning model, (2) there is interaction between the learning model of the website with the interest of learning toward the student's learning result, (3) The learning outcomes of students who have high interest and are learn with the learning model of the website are higher than the results of student learning learn by direct learning model, and (4) the learning outcomes of students who have low interest and learn by direct learning model is not higher than student learning outcomes which is learn by website learning models
\end{abstract}

Keywords: Result of statistics study, instructional model, study interest, website, direct learning

\begin{abstract}
Abstrak: Tujuan penelitian ini adalah menguji pengaruh model pembelajaran dan minat belajar terhadap hasil belajar statistik. Penelitian ini dilakukan pada mahasiswa Program Studi Teknik Mesin, Universitas Negeri Jakarta Tahun 2017. Sampel 64 mahasiswa dari 2 (dua) kelas berdasarkan pengukuran minat belajar. Penelitian menggunakan metode eksperimen dengan rancangan Treatment by Level $2 \times 2$. Analisis data menggunakan ANAVA dua jalur dilanjutkan dengan uji Tukey. Hasil penelitian menunjukan bahwa: (1) hasil belajar mahasiswa yang belajar dengan model pembelajaran website lebih tinggi daripada hasil belajar mahasiswa yang belajar dengan model pembelajaran langsung, (2) terdapat interaksi antara model pembelajaran website dengan minat belajar terhadap hasil belajar mahasiswa, (3) Hasil belajar mahasiswa yang memiliki minat tinggi dan belajar dengan model pembelajaran website lebih tinggi daripada hasil belajar mahasiswa yang belajar dengan model pembelajaran langsung, dan (4) hasil belajar mahasiswa yang memiliki minat rendah dan belajar dengan model pembelajaran website lebih rendah daripada hasil belajar mahasiswa yang belajar dengan model pembelajaran langsung.
\end{abstract}

Kata kunci: hasil belajar statistik, model pembelajaran, minat belajar, website, pembelajaran langsung

\footnotetext{
${ }^{1}$ Budi Prasetya. Universitas Negeri Jakarta (UNJ), email; budipascaunj@gmail.com, contact person; 081280891142

2 Program Studi Teknologi Pendidikan Pascasarjana UNJ, email: hartatimuhctar@yahoo.com

${ }^{3}$ Program Studi Teknologi Pendidikan Pascasarjana UNJ, email: zulfiatisyahrial@gmail.com
} 


\section{PENDAHULUAN}

Di era modern ini, tidak hanya orang dewasa saja yang dapat menikmati canggihnya teknologi, tetapi anak kecil pun dapat menikmatinya. Makin canggih teknologi, makin banyak pula peminatnya, contohnya internet. Internet yang sudah ada sejak tahun 1995 ini tidak hanya dibutuhkan oleh karyawan kantor ataupun pekerja lainnya, karena kini internet bisa juga digunakan dalam pendidikan. Dalam bidang pendidikan, pemanfaatan internet pun sudah mulai digunakan sebagai media pembelajaran untuk dapat menunjang sistem kurikulum sekolah, misalnya website untuk penyampaian pem-belajaran di perguruan tinggi. Jadi, tidak hanya melakukan pembelajaran langsung tatap muka dan membaca buku yang dapat mengolah dan mendapatkan informasi, website pun dapat digunakan karena sudah ada e-modul pengganti buku yang disimpan dihostingan berbentuk media website sebagai bahan pembelajaran dan mempermudah pembelajaran kapan dan di mana saja bahkan lebih meluas, mahasiswa dapat mengambil bahan-bahan perkuliahan, mengakses jurnal (hasil penelitian) dan pengetahuan lainnya dari internet.

Kemajuan teknologi di era digital sekarang sangat cepat, sehingga belum kita menguasai teknologi yang baru sudah beralih ke tekhnologi yang lain (terbaru). Dalam menyikapi hal ini seorang guru ataupun dosen dituntut untuk belajar mandiri atau mengikuti pelatihan-pelatihan, dengan demikian guru ataupun dosen dapat memanfaatkan teknologi demi mempermudah pembelajaran di kelas. Sebab adanya tugas tambahan jadwal dosen ataupun guru menjadi padat, adakalanya dosen tidak hadir, sehingga ketidakhadirannya dapat digantikan dengan pembelajaran mandiri yaitu website. Mahasiswa atau siswa tidak merasa dirugikan karena ketidakhadiran guru ataupun dosen. Selain itu pemanfaatan teknologi dan informasi dapat membuat mahasiswa belajar mandiri karena materi sudah dapat digunakan langsung di internet ataupun website dengan cara googling materimateri kuliah, didownload ataupun langsung dipelajari di dalam website.

Pembelajaran berbasis web atau pendi-dikan jarak jauh dapat digunakan pada semua jalur, jenjang dan jenis pendidikan sebagaimana yang dimaksud di dalam Undang-Undang (2003: 12). Berikut adalah isi 3 ayat dari salah satu pasal 31 di dalam Undang-Undang Republik Indonesia Nomor 20 Tahun 2003 Tentang Sistem Pendidikan Nasional, yaitu: (1) Pendidikan jarak jauh dapat diselenggarakan pada semua jalur, jenjang, dan jenis pendidikan. (2) Pendidikan jarak jauh berfungsi memberikan layanan pendidikan kepada kelompok masyarakat yang tidak dapat mengikuti pendidikan secara tatap muka atau reguler. (3) Pendidikan jarak jauh diselenggarakan dalam berbagai bentuk, modus, dan cakupan yang didukung oleh sarana dan layanan belajar serta sistem penilaian yang menjamin mutu lulusan sesuai dengan standar nasional pendidikan. (4) Ketentuan mengenai penyelenggaraan pendidikan jarak jauh sebagaimana dimaksud dalam ayat (1), 
ayat (2), dan ayat (3) diatur lebih lanjut dengan Peraturan Pemerintah dan ayat (3) diatur lebih lanjut dengan Peraturan Pemerintah dan ayat (3) diatur lebih lanjut dengan Peraturan Pemerintah.

Banyak faktor yang mempengaruhi ketidaklulusan mahasiswa, salah satunya cara penyampaian pembelajaran dosen, media yang digunakan dalam pembelajaran, metode ataupun model pembelajaran dengan mahasiswa berpengaruh terhadap hasil belajar mahasiswa.

Menurut salah satu dosen pengajar statistik di UNJ, menunjukan bahwa pada pembelajaran statistik di kelas belum menggunakan media website sebagai alat bantu pembelajaran, pembelajaran terbatas hanya di kelas dan pembelajaran menggunakan direct learning di mana pembelajaran di kelas terpusat pada dosen. Waktu kehadiran di kelas seminggu sekali 2 sks sehingga mahasiswa perlu menunggu lama untuk feed back bila ada ujian untuk mengetahui nilai atau ingin diskusi dengan dosen mata kuliah statistik bila ada isi materi yang kurang dimengerti.

Nilai hasil belajar merupakan salah satu acuan yang sering digunakan untuk menggambarkan hasil belajar rendah atau tinggi pada mata kuliah, termasuk di dalam perkuliahan pembelajaran statistik. Rata-rata nilai hasil belajar statistik di jurusan tehnik mesin Universitas Negeri Jakarta semester 103 dan 104 untuk dua semester turut di nilai kurang. 60 dan 65 , rata-rata 60 persen mendapatkan nilai $\mathrm{C}$.
Penggunaan media website diharapkan dapat memacu mahasiswa untuk intensif mencari sumber belajar selain dari dosen dan mahasiswa dituntut untuk kreatif dalam memecahkan sebuah masalah menggunakan tekhnologi internet dan media website di samping itu dari segi dosen pemilihan media website dapat mempermudah dosen dalam manage waktu, tidak perlu hadir di dalam kelas melainkan melalui media website, ketika dosen atau pengajar berhalangan hadir dikarenakan adanya tugas-tugas tambahan, oleh karena itu peneliti mencoba menggunakan media website sebagai threatment pada pembelajaran mata kuliah statistik.

\section{Hasil Belajar Statistik}

Menurut Musfiqon (2012:180), belajar adalah suatu proses yang kompleks yang terjadi pada setiap orang sepanjang hidupnya, sejak dilahirkan hingga manusia mati. Proses belajar terjadi karena adanya interaksi antara seseorang dan lingkungan sekitarnya. Belajar dapat terjadi kapan saja dan di mana saja. Salah satu pertanda bahwa seseorang itu telah belajar adalah adanya perubahan tingkah laku pada diri seseorang, yang disebabkan telah terjadi perubahan pada tingkat pengetahuan, keterampilan, atau sikapnya. Seseorang akan belajar sepanjang hidupnya, sehingga dapat meningkatkan pengetahuan, keterampilan atau sikapnya.

Selanjutnya Syah (1997:11) mengatakan bahwa hasil belajar merupakan taraf keberhasilan mahasiswa dalam mempelajari materi pelajaran di 
sekolah dinyatakan dalam bentuk skor yang diperoleh dari hasil tes mengenai sejumlah materi pelajaran tertentu.

Menurut Hasan (2009:1) Statistik adalah ilmu yang mempelajari tentang seluk beluk data, yaitu tentang pengumpulan, pengolahan, penafsiran, dan penarikan kesimpulan dari data yang berbentuk angka-angka. Sudjana (2005:2), mengemukakan bahwa statistik untuk menyatakan kumpulan data, bilangan maupun nonbilangan yang disusun dalam tabel atau diagram yang melukiskan dan menggambarkan suatu persoalan. Melalui statistik dapat menyatakan kesimpulan dari suatu permasalahan ataupun penyelesaian.

Sementara menurut Sudijono (2012: 4), statistik adalah ilmu pengetahuan yang membahas (mempelajari) dan mengembangkan prinsipprinsip, metode dan prosedur yang perlu ditempuh atau dipergunakan dalam rangka: 1) Pengumpulan data angka; 2) Penyusunan atau pengaturan data angka; 3) Penyajian atau penggambaran atau pelukisan data angka; 4) Penganalisisan terhadap data angka, dan Penarikan kesimpulan (conclusion), pembuatan perkiraan (estimation), serta penyusunan ramalan (prediction) secara ilmiah (dalam hal ini secara matematik) atas dasar kumpulan data angka tersebut.

Berdasarkan penjelasan di atas, dapat disimpulkan bahwa yang dimaksud hasil belajar statistik adalah kemampuan yang dimiliki mahasiswa setelah ia menerima pengalaman belajarnya yang berupa kemampuan kognitif, afektif dan psikomotorik dan salah satu dari solusi pemecahan masalah untuk penelitian, membuat keputusan dan lainnya.

\section{Model Pembelajaran}

Pembelajaran merupakan suatu proses yang terdiri atas kombinasi dua aspek, yaitu: belajar tertuju kepada apa yang harus dilakukan oleh siswa, pembelajaran berorientasi pada apa yang harus dilakukan oleh guru sebagai pemberi pembelajaran (Jihad dam Haris, 2012:11). Pembelajaran terjadi karena adanya suatu interaksi guru terhadap murid dan murid terhadap pelajarannya.

Menurut pandangan Joyce di dalam Trianto (2014:23), model pembelajaran adalah suatu perencanaan atau suatu pola yang digunakan sebagai pedoman dalam merencanakan pembelajaran di kelas atau pembelajaran dalam tutorial dan untuk menentukan perangkat-perangkat pembelajaran termasuk di dalamnya buku, film, komputer, kurikulum, dan lain-lain.

Model pembelajaran adalah merupakan sebuah perencanaan pembelajaran yang menggambarkan proses yang ditempuh pada proses pembelajaran agar dicapai perubahan spesifik pada perilaku siswa seperti yang diharapkan (Wahab, 2008:52). Model dalam pembelajaran merupakan langkah-langkah yang dijalani dalam proses pembelajaran.

\section{Model Pembelajaran Website}

Website adalah keseluruhan halamanhalaman web yang terdapat dari sebuah domain 
yang mengandung informasi. Sebuah website biasanya dibangun atas banyak halaman web yang saling berhubungan. Hubungan antara satu halaman web dengan halaman web yang lainnya di sebut dengan Hyperlink sedangkan teks yang dijadikan media penghubung disebut Hypertext (Mooduto dkk, 2006:1). Website berisi dengan halaman-halaman yang terhubung dengan menggunakan Hyperlink.

Non-Profit Organization website, dimiliki oleh organisasi yang bersifat non-profit atau tidak bersifat bisnis (Hidayat, 2010:4). Berdasarkan definisi ini dapat disimpulkan, bahwa website adalah sekumpulan halaman yang berhubungan menampilkan konten atau sesuatu yang bisa diakses atau dibuka apabila kita mengakses internet, mempunyai halaman awal (homepage) yang digunakan untuk menampilkan informasi dan menampilkan apa saja yang diinginkan oleh pemiliknya dengan harapan bisa diakses oleh siapa saja yang terkoneksi di internet dan menghubungi alamat website tersebut.

Berdasarkan penjelasan di atas dapat disimpulkan bahwa, model pembelajaran berbasis web merupakan suatu kegiatan pembelajaran memanfaatkan media situs (website) yang bisa diakses melalui jaringan internet, di mana didalamnya terdapat langkahlangkah harus dijalani dalam proses pembelajaran, memberikan pengalaman terhadap anak diberikan guru dalam bentuk kegiatan yang mengubah tingkah laku anak menjadi lebih baik.

\section{Model Pembelajaran Langsung}

Menurut Arends dalam Trianto (2012:41) model pembelajaran langsung adalah salah satu pendekatan mengajar yang dirancang khusus untuk menunjang proses belajar siswa yang berkaitan dengan pengetahuan deklaratif dan pengetahuan prosedural yang terstruktur dengan baik yang dapat diajarkan dengan pola kegiatan yang bertahap, selangkah demi selangkah.

Sintaks Model Pembelajaran Langsung menurut Kardi dan Nur dalam Trianto.

Fase 1; Menyampaikan tujuan dan mempersiapkan siswa.

Fase 2; Mendemonstrasikan pengetahuan dan keterampilan.

Fase 3; Membimbing pelatihan.

Fase 4; Mengecek pemahaman dan memberikan umpan balik.

Fase 5; Memberikan kesempatan untuk pelatihan lanjutan dan penerapan (Trianto:43).

Model Pembelajaran Langsung adalah suatu perencanaan atau suatu pola yang digunakan sebagai pedoman dalam merencanakan pembelajaran di kelas untuk menunjang proses belajar siswa yang berkaitan dengan pengetahuan deklaratif dan pengetahuan prosedural yang terstruktur dengan baik yang dapat diajarkan dengan pola kegiatan yang bertahap, selangkah demi selangkah. 
Arti dari penjelasan-penjelasan di atas diduga bahwa kelebihan pembelajaran web dapat memudahkan pengajar memudahkan membagi waktu dalam mengajar dan dapat mengajar di mana saja jika berhalangan hadir, disisi peserta didik bisa belajar lebih mandiri dan mendapat feedback dari pengajar lebih cepat tanpa menunggu lama dipertemuan selanjutnya bila ada tugas, kuis ataupun ujian serta materi yang kurang dipahami.

\section{Minat Belajar}

Minat merupakan salah satu aspek psikis manusia yang dapat mendorong untuk mencapai tujuan seseorang yang memiliki minat terhadap suatu objek, cenderung untuk memberikan perhatian atau merasa senang yang lebih besar terhadap objek tersebut. Apabila objek tersebut tidak menimbulkan rasa senang, maka minat terhadap objek tersebut akan hilang.

Jones (1968:95) mendefinisikan minat sebagai perasaan suka yang berhubungan dengan suatu reaksi terhadap sesuatu yang khusus atau situasi tertentu. Garret (1965:187) menjelaskan minat sebagai aktivitas yang menyertai seseorang individu melalui nilai-nilai perasaan dan pikiran yang disukainyaMinat merupakan dorongan untuk memberikan perhatian terhadap sesuatu objek yang disertai dengan keinginan untuk mengetahuinya lebih lanjut.

Objek tersebut dapat diketahui dan dipelajari melalui proses belajar atau melalui pengalaman. Proses ini merupakan gejala psikis yang erat hubungannya dengan kesadaran seseorang terhadap kebutuhan, sehingga menimbulkan keinginan untuk memenuhinya. Besarnya kesadaran terhadap yang diminati serta besarnya manfaat dan kegunaannya yang dirasakan, akan mempengaruhi kualitas aktifitas yang dilakukan.

Menurut Slameto dikutip oleh Djaali (2008:121) minat adalah rasa lebih suka dan rasa ketertarikan pada suatu hal atau aktivitas, tanpa ada yang menyuruh. Minat pada dasarnya adalah penerimaan akan suatu hubungan antara diri sendiri dengan sesuatu di luar diri. Semakin kuat atau dekat hubungan tersebut, semakin besar minatnya. Hal ini senada dengan pendapat Witty dikutip oleh Taringan (1989:104) memberikan rumusan minat sebagai ciri keinginan yang dilakukan melalui tindakan oleh individu yang dicobanya melalui obyek yang dipilihnya, kegiatannya, ketrampilannya dan ditujukan pada hal yang disukai.

Skinner (1958:274) mengungkapkan bahwa dalam pembelajaran ada beberapa hal yang dapat mempengaruhi minat belajar dan untuk dapat membangkitkan minat mahasiswa, seorang pendidik harus dapat mengubah proses belajar yang membosankan menjadi pengalaman belajar yang menggairahkan, caranya antara lain sebagai berikut; 1) Materi yang dipelajari harus menjadi menarik dan menimbulkan suasana yang baru, misalnya dalam bentuk permainan, diskusi atau pemberian tugas di luar sekolah sebagai variasi kegiatan. 2) Materi pembelajaran menjadi menarik jika mahasiswa tahu tujuan dari pembelajaran. 3) 
Minat mahasiswa terhadap pelajaran dapat ditingkatkan dengan variasi metode yang digunakan. 4) Minat mahasiswa juga dapat dibangkitkan kalau mahasiswa mengetahui manfaat atau kegunaan dari pelajaran itu bagi dirinya.

Pendapat senada juga dikemukan oleh Crow dan Crow (1989:249) yang berpendapat bahwa minat yang telah disadari terhadap bidang pelajaran mungkin sekali akan menjaga pikiran mahasiswa sehingga dapat menguasai pelajaran, pada gilirannya prestasi yang dicapai akan menambah minatnya yang bisa berlanjut sepanjang hayat.

Sejalan dengan pendapat ini Sabri (2007:84) mengemukakan bahwa minat yang dapat menunjang belajar adalah minat kepada bahan atau mata pelajaran. Menurut Sefrina (2013:28) minat merupakan ketertarikan akan sesuatu objek yang berasal dari hati, bukan karena paksaan dari orang lain. Minat terhadap sesuatu muncul karena eksplorasi dan manipulasi yang dilakukan (Purwanto, 2007:66). Sebelum adanya minat, motif muncul terlebih dahulu.

Minat berpengaruh kepada hasil belajar, semakin tinggi minat seseorang terhadap suatu materi maka akan timbul rasa senang dan tekun dalam melakukan aktivitas belajar, sebaliknya makin rendah minat seseorang maka tidak ada dorongan untuk melakukan aktivitas belajar. Berdasarkan teori dan konsep di atas disimpulkan bahwa minat belajar adalah dorongan yang bersifat psikologis dari individu untuk menguasai materi pembelajaran karena adanya keinginan untuk belajar, rasa suka dan senang, tertarik dan berperan aktif di dalam pembelajaran.

Adapun beberapa penelitian yang relevan dengan penelitian ini. Diantaranya adalah dilakukan oleh Erfan Priyambodo, Antuni Wiyarsi, dan Rr. Lis Permana Sari (2012:108). Hasil penelitian Pengaruh Media Pembelajaran Interaktif Berbasis Website terhadap Motivasi Belajar Mahasiswa diperoleh hasil bahwa Pembelajaran dengan menggunakan media interaktif berbasis web berperan dalam meningkatkan ketertarikan mahasiswa dalam belajar dan meningkatkan motivasi belajar mahasiswa.

Hasil Penelitian Farin Triana dan Rochmawati (2014:4) Perbedaan Hasil Belajar Mahasiswa Pembelajaran yang Menggunakan dan Tanpa Menggunakan Media Berbasis Web MOODLE Pada Materi Mengelola Kartu Aktiva Tetap di XI AK SMK Negeri 10 Surabaya diperoleh hasil bahwa terdapat perbedaan yang signifikan antara hasil belajar mahasiswa yang menerapkan model pembelajaran langsung dengan menggunakan media berbasis web moodle dan yang menerapkan model pembelajaran langsung tanpa menggunakan media berbasis web moodle. Perbedaan yang signifikan tersebut menunjukkan bahwa penerapan model pembelajaran langsung dengan menggunakan media berbasis web moodle dapat mempengaruhi hasil belajar mahasiswa. Hasil belajar yang menerapkan model pembelajaran langsung dengan menggunakan 
media berbasis web moodle lebih baik daripada yang menerapkan model pembelajaran langsung tanpa menggunakan media berbasis web moodle.

Manfaat yang didapat dari hasil penelitian ini adalah sebagai berikut: 1) Bagi dosen, Penelitian ini akan memberikan pengalaman bermanfaat dalam mengajar dan sangat membantu jika dosen berhalangan untuk hadir mengajar dengan melakukan pengajaran tanpa hadir di kelas. Pengalaman dosen dapat mengembangkan model pemblajaran pada pokok pembahasan yang lain atau mata kuliah yang lain. 2) Bagi mahasiswa, Penelitian ini akan sangat memberikan manfaat karena secara langsung dapat mempermudah belajar kapan saja dan di mana saja yang sangat membantu bagi mahasiswa untuk meningkatkan hasil belajar mereka secara optimal. 3) Untuk Perkembangan Ilmu Pengetahuan, Penelitian ini sangat bermanfaat bagi pengembangan pembelajaran online berbasis website yang menyajikan materi secara online. Hasil penelitian ini akan memberikan informasi yang rinci tentang media pembelajaran berbasis website di mata kuliah statistik yang tertuju secara experimen.

Penelitian ini bertujuan untuk mengetahui pengaruh dari variabel-variabel bebas, yaitu pembelajaran Website dan yang diajar dengan Pembelajaran Langsung (direct learning), serta minat belajar mahasiswa tentang statistik (tinggi dan rendah) terhadap variabel terikat yaitu hasil belajar statistik. Di samping itu, ingin juga diketahui ada tidaknya pengaruh interaksi antara kedua variabel bebas tersebut dalam mempengaruhi hasil belajar statistik.

\section{METODE PENELITIAN}

Metode penelitian ini menggunakan metode eksperimen yang menggunakan pola pengaruh antara variabel bebas terhadap variabel terikat. Maka dari itu, dalam penelitian ini terdapat satu kelas yang mendapatkan perlakuan (experimen) yang menggunakan model pembelajaran website dan satu kelas kontrol atau kelas pembanding menggunakan model pembelajaran langsung. Variabel bebas atribut dalam penelitian ini adalah minat belajar, yang dibagi menjadi minat belajar tinggi dan minat belajar rendah yang dimiliki mahasiswa fakultas teknik mesin Universitas Negeri Jakarta. Angkatan 2015.

Rancangan penelitian ini menggunakan ANAVA Treatment by Level 2x 2, dengan matriks sebagai berikut:

Tabel 1. Matriks Rancangan Perlakuan

\begin{tabular}{|c|r|r|}
\hline $\begin{array}{l}\text { Website (A) } \\
\text { Belajar (B) }\end{array}$ & $\begin{array}{c}\text { Website } \\
\text { (individual) } \\
\text { (A1) }\end{array}$ & $\begin{array}{c}\text { Langsung } \\
\text { (direct learning) } \\
\text { (A2) }\end{array}$ \\
\hline Tinggi (B1) & $\begin{array}{r}\mathrm{A}_{1} \mathrm{~B}_{1} \\
\mathrm{X}_{11 \mathrm{k}}\end{array}$ & $\begin{array}{r}\mathrm{A}_{2} \mathrm{~B}_{1} \\
\mathrm{X}_{21 \mathrm{k}} \\
\end{array}$ \\
$\mathrm{k}=1,2, \ldots, \mathrm{n}_{11}$ & $\mathrm{k}=1,2, \ldots, \mathrm{n}_{21}$ \\
\hline Rendah (B2) & $\mathrm{A}_{1} \mathrm{~B}_{2}$ & $\mathrm{~A}_{2} \mathrm{~B}_{2}$ \\
& $\mathrm{X}_{12 \mathrm{~K}}$ & $\mathrm{X}_{22 \mathrm{k}}$ \\
& $\mathrm{k}=1,2, \ldots, \mathrm{n}_{12}$ & $\mathrm{k}=1,2, \ldots, \mathrm{n}_{22}$ \\
\hline
\end{tabular}

Keterangan:

$\mathrm{A}_{1}=$ Kelompok yang diberikan model Pembelajaran dengan Website.

$\mathrm{A}_{2}=$ Kelompok yang diberikan model Pembelajaran Langsung (direct learning) 


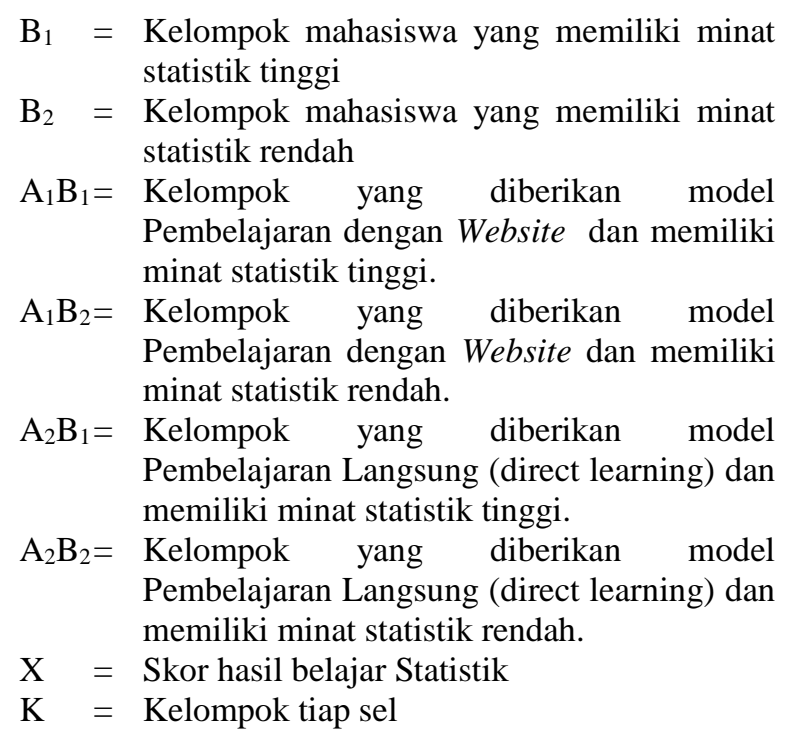

Dalam penelitian ini yang menjadi populasi target adalah seluruh mahasiswa Program Studi Pendidikan Teknik mesin Universitas Negeri Jakarta. Meskipun demikian, karena penelitian ini tentang hasil belajar statistik pada mahasiswa tahun akademik 2016/2017, maka populasi terjangkau dalam penelitian ini adalah mahasiswa angkatan 2015 yang terdiri dari 4 (empat) kelas dengan jumlah mahasiswa sebanyak 140 orang. Adapun untuk menentukan sampel dalam penelitian ini dilakukan dengan cara random dari 4 (empat) kelas yang masing-masing kelas terdiri dari 16 orang. Setelah didapat kelas yang akan diteliti, kemudian sampel tersebut dikelompokkan dalam dua kelas, yaitu kelas kontrol dan kelas eksperimen. Kelas kontrol adalah kelompok mahasiswa yang dalam pembelajaran di kelas menggunakan model pembelajaran langsung. Kelas eksperimen adalah kelompok mahasiswa yang dalam pembelajaran di kelas menggunakan model pembelajaran website. Untuk menentukan kelas eksperimen dan kelas kontrol juga dilakukan secara random.

Menentukan kelompok mahasiswa dengan minat belajar tinggi dan mahasiswa dengan minat belajar rendah, dilakukan dengan cara menghitung skor yang mahasiswa peroleh pada saat diukur dengan menggunakan kuesioner minat belajar. Hasil data skor yang telah didapat mahasiswa melalui pengisian kuesioner akan diurutkan dari yang paling besar hingga yang paling kecil. Sebanyak $27 \%$ dari kelompok atas (skor mahasiswa dari yang paling besar) dikategorikan sebagai mahasiswa dengan minat belajar tinggi, dan sebanyak 27\% dari kelompok bawah (skor mahasiswa dari yang paling kecil) dikategorikan sebagai mahasiswa dengan minat belajar rendah. Jika dalam kelas kontrol dan kelas eksperimen masing-masing terdiri dari 31 orang mahasiswa, maka yang akan dijadikan sampel dalam penelitian untuk setiap kelasnya adalah $31 \times 27 \%=8,37$, atau dibulatkan menjadi 8 orang untuk mahasiswa minat belajar tinggi, dan 8 orang untuk mahasiswa dengan minat belajar rendah. Sehingga total sampel dalam penelitian ini berjumlah 32 orang mahasiswa.

Sebelum dilaksanakan perlakuan, terlebih dahulu dilihat faktor kesamaan dari kedua kelompok, yakni kesamaan dalam faktor-faktor yang mempengaruhi pelaksanaan kegiatan pembelajaran. Maka dari itu peneliti yakin bahwa kedua kelompok eksperimen dan kelompok kontrol mempunyai karakteristik yang sama (faktor tujuan yang sama, dosen, kurikulum yang 
sama, program studi yang sama dan tempat perkuliahan sama) kecuali dalam hal perlakuan pembelajaran.

Dalam penelitian ini, adapun hal-hal yang perlu disiapkan adalah: (a) Membuat kuesioner untuk menentukan sampel kelompok mahasiswa minat belajar tinggi dan minat belajar rendah. Mulai dari penyusunan definisi operasional, kisikisi, sampai dengan validasi butir pernyataan; (b) Menyusun RPKPS (Rencana Program dan Kegiatan Pembelajaran Semester) yang sesuai dengan model pembelajaran website; (c) Membuat soal-soal tes hasil belajar mahasiswa pada saat pelaksanaan dan sesudah pembelajaran. Pembuatan tes hasil belajar dilakukan dari mulai perancangan kisi-kisi sampai dengan validasi ahli butir soal.

Langkah-langkah yang akan dilakukan selama proses penelitian yaitu: (a) Memberikan kuesioner minat belajar kepada mahasiswa agar dapat diisi dan hasilnya dapat ditentukan kelompok mahasiswa dengan minat belajar tinggi dan minat belajar rendah; (b) Membagi 2 (dua) kelas, yang terdiri dari kelas perlakuan dan kelas kontrol. Pada masing-masing kelas, terdapat kelompok mahasiswa dengan minat belajar tinggi dan minat belajar rendah. Pada kelas eksperimen ( program studi : SI 2015 B dan SI 2015 D ) diterapkan model pembelajaran website sedangkan pada kelas kontrol (program studi : SI 2015 A dan SI 2015 C) diterapkan model pembelajaran langsung; (c) Mahasiswa diberikan tes pada waktu di tengah pembelajaran dan di akhir pembelajaran untuk mengetahui hasil perbedaan perlakuan; (d) Dosen melakukan pembelajaran sesuai dengan RPKPS yang telah dibuat untuk masing-masing kelas, yaitu kelas kontrol dan kelas eksperimen.

Setelah perlakuan selesai dilakukan, dosen memberikan tes hasil belajar untuk mengetahui perbedaan hasil belajar mahasiswa yang diajar dengan model pembelajaran website dan mahasiswa yang diajar dengan model pembelajaran langsung. Keseluruhan data hasil penelitian dirangkum untuk kemudian diolah berdasarkan statistik deskriptif dan statistik inferensial agar dapat menguji hipotesis yang ada. Data hasil tes hasil belajar mahasiswa dianalisis secara statistik inferensial, sedangkan data hasil kuesioner mahasiswa dianalisis secara statistik deskriptif.

\section{HASIL DAN PEMBAHASAN}

Data yang digunakan untuk variabel hasil belajar statistik didapat dari tes hasil belajar statistik mahasiswa kelas kontrol dan kelas eksperimen, yaitu kelas yang menggunakan Model Pembelajaran langsung untuk kelas kontrol dan Model pembelajaran website untuk kelas eksperimen. Instrumen hasil belajar statistik terdiri dari 6 butir pertanyaan yang telah divalidasi ahli.

Data hasil belajar statistik yang didapat kemudian dikelompokkan sesuai dengan namanama mahasiswa yang menjadi sampel dalam penelitian. Pada setiap kelas, baik kelas kontrol maupun kelas eksperimen, terdapat 2 (dua) kelompok sampel berdasarkan minat belajarnya, 
yakni sebanyak 8 mahasiswa pada kelompok minat belajar rendah dan 8 mahasiswa pada kelompok minat belajar tinggi, sehingga jumlah sampel dalam penelitian ini 16 orang mahasiswa untuk kelas kontrol dan 16 orang mahasiswa untuk kelas eksperimen. Data hasil belajar statistik dapat dilihat pada tabel 2 .

\section{Tabel 2. Rerata Hasil Belajar Statistik}

\begin{tabular}{|c|c|c|c|c|c|c|c|}
\hline \multirow{2}{*}{\multicolumn{2}{|c|}{$\begin{array}{c}\text { Hasi } \\
\text { Belajar } \\
\text { Statisti } \\
\text { k. }\end{array}$}} & \multicolumn{4}{|c|}{ Model Rembelajaran } & \multirow{2}{*}{\multicolumn{2}{|c|}{ Total }} \\
\hline & & \multicolumn{2}{|c|}{ (Website) $A_{1}$} & \multicolumn{2}{|c|}{$\begin{array}{c}\text { (Langsyng) } \\
\mathrm{A}_{2}\end{array}$} & & \\
\hline \multirow{10}{*}{ 蔓 } & \multirow{5}{*}{ 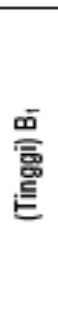 } & $n_{1}=$ & 78 & $\mathrm{n}_{2}=$ & 18 & $n_{b 1}=$ & 32 \\
\hline & & $\begin{array}{l}\mathbb{a X _ { 1 }} \\
=\end{array}$ & 1189 & $\begin{array}{c}\square X_{2} \\
=\end{array}$ & 949 & $\begin{array}{l}\text { DXa1 } \\
=\end{array}$ & 2138 \\
\hline & & $\begin{array}{c}\mathrm{DX}_{n}{ }^{2} \\
=\end{array}$ & $\begin{array}{c}8939 \\
5\end{array}$ & $\begin{array}{l}\square X_{2} \\
z=\end{array}$ & 57515 & $\begin{array}{l}\square X_{\theta_{1}}{ }^{2} \\
=\end{array}$ & $\begin{array}{c}14691 \\
0\end{array}$ \\
\hline & & $x_{1}=$ & 74,31 & $x_{2}=$ & 59,31 & $x_{b 1}=$ & 86,81 \\
\hline & & $\begin{array}{c}\left(\square X_{1}\right) \\
2=\end{array}$ & $\begin{array}{c}1413 \\
721\end{array}$ & $\begin{array}{l}(\square X \\
1)^{2}=\end{array}$ & $\begin{array}{c}90060 \\
1\end{array}$ & $\begin{array}{c}\left(\square X_{b 1}\right. \\
)^{2}=\end{array}$ & $\begin{array}{c}45710 \\
44\end{array}$ \\
\hline & \multirow{5}{*}{ 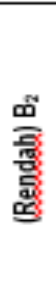 } & $\mathrm{nz}=$ & 18 & $\mathrm{n}_{4}=$ & 18 & $\mathrm{n}_{\square 2}=$ & 32 \\
\hline & & $\begin{array}{l}\square X_{z} \\
=\end{array}$ & 963 & $\begin{array}{c}\square X_{4} \\
=\end{array}$ & 1031 & $\begin{array}{c}\mathrm{DX} \times 2 \\
=\end{array}$ & 1994 \\
\hline & & $\begin{array}{l}\mathrm{DX}_{\mathrm{I}^{2}} \\
=\end{array}$ & $\begin{array}{c}5903 \\
5\end{array}$ & $\begin{array}{l}\square X_{4} \\
2=\end{array}$ & 67175 & $\begin{array}{c}\square X x^{2} \\
=\end{array}$ & $\begin{array}{c}12621 \\
0\end{array}$ \\
\hline & & $x_{2}=$ & 80,19 & $x_{4}=$ & 64,44 & $\mathrm{x}_{\mathrm{bz}}=$ & 62,31 \\
\hline & & $\begin{array}{c}\left(\square X_{z}\right) \\
2=\end{array}$ & $\begin{array}{c}9273 \\
69\end{array}$ & $\begin{array}{l}(\text { DX } \\
4)^{2}=\end{array}$ & $\begin{array}{c}10629 \\
61\end{array}$ & $\begin{array}{c}\left(\square X_{b 2}\right. \\
)^{2}=\end{array}$ & $\begin{array}{c}39760 \\
36\end{array}$ \\
\hline \multirow{5}{*}{\multicolumn{2}{|c|}{ Total }} & $\mathrm{n}_{\mathrm{k},}=$ & 32 & $\begin{array}{c}\mathrm{n}_{k 2} \\
=\end{array}$ & 32 & $D_{2}=$ & 64 \\
\hline & & $\begin{array}{c}\square X_{* 1} \\
=\end{array}$ & 2152 & $\begin{array}{l}\square X_{k} \\
z=\end{array}$ & 1980 & $\square x_{1}=$ & 4132 \\
\hline & & $\begin{array}{c}\begin{array}{c}\square X_{21}{ }^{2} \\
=\end{array}\end{array}$ & $\begin{array}{c}1484 \\
30\end{array}$ & $\begin{array}{l}\square X_{k} \\
z^{2}=\end{array}$ & $\begin{array}{c}12469 \\
0\end{array}$ & $\begin{array}{c}\square X_{t}{ }^{2} \\
=\end{array}$ & $\begin{array}{c}27312 \\
0\end{array}$ \\
\hline & & $x_{k+1}=$ & 67,25 & $x_{k a}=$ & 61,88 & $z_{4}=$ & $\begin{array}{c}64,56 \\
3\end{array}$ \\
\hline & & $\begin{array}{c}\left(a X_{k-1}\right. \\
)^{2}=\end{array}$ & $\begin{array}{c}4631 \\
104\end{array}$ & $\begin{array}{l}(\mathrm{DX} \\
\mathrm{xa})^{2} \\
=\end{array}$ & $\begin{array}{c}39204 \\
00\end{array}$ & $\begin{array}{c}\left(\square X_{0}\right) \\
2=\end{array}$ & $\begin{array}{c}17073 \\
424\end{array}$ \\
\hline
\end{tabular}

Keterangan:
$\mathrm{A}_{1}=$ Kelompok yang diberikan model Pembelajaran dengan Website.
$\mathrm{A}_{2}=$ Kelompok yang diberikan model Pembelajaran Langsung (direct learning)
$\mathrm{B}_{1}=$ Kelompok mahasiswa yang memiliki minat statistik tinggi
$\mathrm{B}_{2}=$ Kelompok mahasiswa yang memiliki minat statistik rendah

$\mathrm{N}=$ Jumlah sampel pada setiap kelompok

- $\mathrm{x}=$ Jumlah skor hasil belajar statistik mahasiswa teknik mesin pada masing-masing anggota kelompok

- $\mathrm{x}^{2}=$ Jumlah skor hasil belajar statistik mahasiswa teknik mesin pada masing-masing anggota kelompok yang dikuadratkan

$\mathrm{X}=$ Skor rata-rata hasil belajar statistik teknik mesin pada masing-masing kelompok

Teknik statistik inferensial mensyaratkan adanya model distribusi untuk menaksir parameter populasi. Maka karena itu, sebelum melakukan pengujian hipotesis perlu dilakukan pengujian model distribusi normal yang digunakan untuk menentukan bahwa data setiap variabel penelitian yang akan dianalisis membentuk kurva distribusi normal. Proses pengujian persyaratan analisis dalam penelitian ini merupakan syarat yang harus dipenuhi agar penggunaan teknik analisis varian yang termasuk pada kelompok statistik parametris dapat diterapkan untuk keperluan pengujian hipotesis.

\section{Tabel 3. Hasil Anava Dua Jalan}

\begin{tabular}{|c|c|c|c|c|c|c|c|}
\hline \multirow{3}{*}{$\begin{array}{l}\text { Sumber } \\
\text { Variansi } \\
\\
\text { Antar } \\
\text { Kolom }\end{array}$} & \multirow{3}{*}{$\frac{\frac{\mathrm{db}}{-}}{1}$} & \multirow{3}{*}{$\begin{array}{l}\text { JK } \\
462,25\end{array}$} & \multirow{3}{*}{$\begin{array}{l}\text { RJK } \\
462,25\end{array}$} & \multirow{3}{*}{$\begin{array}{l}F_{\text {bitung }} \\
6,799\end{array}$} & \multicolumn{3}{|c|}{$F_{\text {tabel }}$} \\
\hline & & & & & \multicolumn{2}{|c|}{0,05} & \multirow{2}{*}{\begin{tabular}{|l}
0,01 \\
7,08 \\
\end{tabular}} \\
\hline & & & & & $\stackrel{*}{-}$ & 4,00 & \\
\hline $\begin{array}{l}\text { Antar } \\
\text { Baris }\end{array}$ & 1 & 324,00 & 324,00 & 4,766 & $\stackrel{*}{-}$ & 4,00 & 7,08 \\
\hline Interaksi & 1 & 1482,25 & 1482,25 & 21,802 & $\begin{array}{l}* * \\
-\end{array}$ & 4,00 & 7,08 \\
\hline Dalam & 60 & 4079,25 & 67,99 & & - & 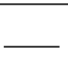 & - \\
\hline $\begin{array}{l}\text { Total } \\
\text { Direduksi }\end{array}$ & 63 & 6347,75 & & & - & $\longrightarrow$ & \\
\hline
\end{tabular}

Keterangan:
* = Signifikan
$\mathrm{JK}=$ Jumlah Kuadrat
$* *=$ Sangat Signifikan
$\mathrm{db}=$ derajat kebebasan 
Penggunaan ANAVA dua jalur untuk melihat 2 (dua) pengaruh utama dan satu pengaruh interaksi. Pengaruh utamanya adalah perbedaan penggunaan model pembelajaran terhadap hasil belajar statistik dan pengaruh minat belajar terhadap hasil belajar statistik. Pengaruh interaksi antara pengaruh penggunaan model pembelajaran dan minat belajar terhadap hasil belajar statistik. Hasil analisis ANAVA dua jalur dilakukan dengan program komputer yaitu Microsoft Excel terangkum pada tabel 3.

Hasil perhitungan pada tabel 2. Di atas dapat disimpulkan bahwa: (1) Hasil perhitungan Anava yang tertera pada tabel 4.2, didapat $\mathrm{F}_{\text {hitung }}=6,799>$ $\mathrm{F}_{\text {tabel }}=4,00$ pada taraf signifikansi $(\alpha)=0,05$, berdasarkan hasil tersebut maka hipotesis nol $\left(\mathrm{H}_{0}\right)$ yang menyatakan : $\mu \mathrm{A}_{1} \leq \mu \mathrm{A}_{2}$ ditolak, artinya terdapat perbedaan rata-rata hasil belajar mahasiswa yang diajar dengan model pembelajaran website Dengan hasil belajar mahasiswa yang diajar dengan pembelajaran langsung, dan hasil belajar mahasiswa yang diajar dengan model pembelajaran website lebih tinggi daripada hasil belajar mahasiswa yang diajar dengan model pembelajaran langsung. (2) Hasil perhitungan Anava, didapat $F_{\text {hitung }}=21,802>F_{\text {tabel }}$ $=4,00$ pada taraf signifikansi $(\alpha)=0,05$, berdasarkan hasil tersebut maka hipotesis nol $\left(\mathrm{H}_{0}\right)$ yang menyatakan : $\mathrm{H}_{0}$ : Int. A X B $=0$ ditolak, artinya terdapat efek interaksi antara model pembelajaran dan minat belajar mahasiswa.
Tabel 4. Ringkasan Hasil Perhitungan Uji Tukey

\begin{tabular}{|c|c|c|c|l|}
\hline Kelompok & $\mathrm{n}$ & $\mathrm{q}_{\text {hitung }}$ & $\mathrm{Q}_{\text {tabel }}$ & Keterangan \\
\hline $\mathrm{q}_{1}$ & 16 & 7,28 & 3,65 & Signifikan \\
\hline $\mathrm{q}_{2}$ & 16 & 2,06 & 3,65 & $\begin{array}{l}\text { Tidak } \\
\text { signifikan }\end{array}$ \\
\hline
\end{tabular}

Berikut hasil perhitungan tabel 3 pada 4 (empat) kelompok data menggunakan Uji Tukey, yaitu: (a) Hasil perhitungan Anava yang tertera pada tabel 4.12, didapat $\mathrm{Q}$ hitung $=7,28>\mathrm{Q}_{\text {tabel }}=$ 3,65 pada taraf signifikansi $(\alpha)=0,05$, berdasarkan hasil tersebut maka hipotesis nol $\left(\mathrm{H}_{0}\right)$ yang menyatakan : $\mu_{\mathrm{A} 1 \mathrm{~B} 1}=\mu_{\mathrm{A} 2 \mathrm{~B} 1}$ ditolak, artinya terdapat perbedaan hasil belajar statistik antara mahasiswa yang mempunyai minat belajar tinggi dan menggunakan model pembelajaran website dan mahasiswa yang mempunyai minat tinggi yang diajar dengan model pembelajaran langsung (direct learning), dan hasil belajar mahasiswa yang diajar dengan model pembelajaran website yang mempunyai minat tinggi lebih besar daripada hasil belajar mahasiswa yang diajar dengan model pembelajaran langsung yang mempunyai belajar minat tinggi. (b) Hasil perhitungan Anava yang tertera pada tabel 4.12, didapat $\mathrm{q}_{\text {hitung }}=2,06>\mathrm{q}_{\text {tabel }}$ $=3,65$ pada taraf signifikansi $(\alpha)=0,05$, berdasarkan hasil tersebut maka hipotesis nol $\left(\mathrm{H}_{0}\right)$ yang menyatakan : $\mu_{\mathrm{A} 1 \mathrm{~B} 1}=\mu_{\mathrm{A} 2 \mathrm{~B} 1}$ diterima, artinya tidak terdapat perbedaan hasil belajar statistik antara mahasiswa yang mempunyai minat belajar rendah dan menggunakan model pembelajaran website dengan mahasiswa yang mempunyai minat rendah yang diajar dengan model pembelajaran 
langsung (direct learning, dan mahasiswa yang diajar dengan model pembelajaran langsung lebih tinggi daripada mahasiswa yang diajar dengan model pembelajaran website.

\section{Pembahasan}

Berdasarkan penelitian kepada mahasiswa yang diberikan perlakuan dengan model pembelajaran dan mengukur hasil belajarnya, selanjutnya diberikan tes untuk melihat hasil belajar mahasiswa, dan diperoleh hasil belajar.

Hipotesis pertama yang menyatakan bahwa model pembelajaran website, memberikan hasil belajar mahasiswa lebih baik dibandingkan dengan model pembelajaran langsung pada mata kuliah statistik. Hipotesis ini terbukti ditunjukkan dengan data ditabel $4.1 \quad \mathrm{X}_{\mathrm{k} 1}>\mathrm{X}_{\mathrm{k} 2}$, artinya model pembelajaran website lebih baik dari model pembelajaran langsung dan pada hasil Uji ANAVA pada tabel 4.11, di mana $\mathrm{F}_{\text {hitung }}=6,799>$ $\mathrm{F}_{\text {tabel }}=4.00$, pada taraf signifikansi $(\alpha)=0.05$, berdasarkan hasil tersebut maka hipotesis nol $\left(\mathrm{H}_{0}\right)$ yang menyatakan $\mu_{\mathrm{A} 1}=\mu_{\mathrm{A} 1}$ ditolak, artinya terdapat perbedaan rata-rata hasil belajar antara dua model pembelajaran, dan mahasiswa yang diajar dengan model pembelajaran website mempunyai hasil belajar yang lebih baik dibandingkan dengan hasil belajar mahasiswa yang diajar dengan model pembelajaran langsung.

Dapat disimpulkan dari segi mahasiswa bahwa, dengan menerapkan model pembelajaran website, mahasiswa lebih dapat cepat belajar mandiri, belajar tidak hanya berpusat pada dosen, tetapi mahasiswa terlatih dan terpacu untuk belajar mandiri dengan mencari sumber-sumber belajar lain yang tidak mesti diberikan oleh dosen contohnya di perpustakaan, internet yang bermedia website dan lainnya. Adapun keuntungannya menggunakan model pembelajaran website lainnya, mahasiswa tidak perlu menunggu lama dipertemuan diselanjutnya untuk bertanya materi yang belum dipahami, bertanya nilai ujian ataupun hanya ingin berkomunikasi dengan dosen karena di website dapat melakukan interaksi tersebut melalui aplikasi real time yaitu fitur chat.

Ditinjau dari sisi dosen, karena adanya berbagai tugas tambahan kemungkinan berhalangan hadir pun juga ada, dengan menggunakan model pembelajaran website dosen pun terbantu bila tidak dapat mengajar dikelas, dosen pun dapat mengajar dari luar kelas tentunya dengan kesepakatan dari mahasiswa dan dosen tersebut, serta mahasiswa tidak dirugikan jika dosen tidak hadir karena penyampaian bahan ajar atau materi pun dapat dilakukan di website.

Selanjutnya untuk hipotesis kedua, hasil penelitian mengenai interaksi antara model pembelajaran dan minat belajar terhadap hasil belajar mahasiswa berhasil dibuktikan hipotesis kedua, yaitu dengan diperolehnya $F_{\text {hitung }}$ yang dignifikan pada perhitungan Uji ANAVA, di mana $\mathrm{F}_{\text {hitung }}=21,802>\mathrm{F}_{\text {tabel }}=4.00$ pada taraf signifikansi $(\alpha) 0.05$, berdasarkan hasil tersebut maka $\mathrm{H}_{0}$ (hipotes nol) yang menyatakan: $\mathrm{H}_{0}$ : Int. A $\mathrm{X} \mathrm{B}=0$, ditolak, dengan demikian terdapat 
interaksi antara model pembelajaran dengan Minat Belajar.

Hipotesis 3 (ketiga) menyatakan bahwa pada minat belajar tinggi, hasil belajar mahasiswa yang diajar dengan Model Pembelajaran website lebih baik dari hasil belajar mahasiswa yang diajar dengan Model Pembelajaran Langsung, dibuktikan dengan nilai qhitung sebagaimana yang telah dijelaskan sebelumnya dalam Uji Tukey, yaitu diperoleh $\mathrm{q}_{\text {hitung }}=7,28<\mathrm{q}_{\text {tabel }}=3.65$ ada taraf signifikansi $(\alpha)$ 0.05, maka dapat disimpulkan bahwa $\mathrm{H}_{0}$ (hipotesis nol) yang menyatakan : $\mathrm{H}_{0}$ : $\mu_{\mathrm{A} 1 \mathrm{~B} 1}=\mu_{\mathrm{A} 2 \mathrm{~B} 1}$, berhasil ditolak, dengan demikian rata-rata hasil belajar mahasiswa yang memiliki minat tinggi dan diajar dengan Model Pembelajaran Website lebih baik dibandingkan yang diajar dengan model pembelajaran langsung, diterima karena signifikan. Artinya hipotesis yang diterima adalah benar, pada kelompok minat tinggi yang diajar dengan model pembelajaran website lebih baik dari kelompok yang diajar dengan model pembelajaran langsung. Hal ini disebabkan karena minat belajar tinggi memiliki pengaruh yang dominan terhadap hasil belajar, sehingga mahasiswa yang memiliki minat belajar tinggi menghasilkan perbedaan hasil belajar yang lebih baik yang sangat menonjol.

Hipotesis 4 (keempat) menyatakan bahwa pada minat belajar rendah, hasil belajar mahasiswa yang diajar dengan Model Pembelajaran Langsung tidak lebih baik dibandingkan dengan mahasiswa yang diajar dengan model pembelajaran website, dibuktikan dengan nilai $\mathrm{q}_{\text {hitung }}$ sebagaimana yang telah dijelaskan sebelumnya dalam Uji Tukey, yaitu diperoleh $\mathrm{q}_{\text {hitung }}=2,06<\mathrm{q}_{\text {tabel }}=3.65$ ada taraf signifikansi $(\alpha)$ 0.05, maka dapat disimpulkan bahwa $\mathrm{H}_{0}$ (hipotesis nol) yang menyatakan : $\mathrm{H}_{0}$ : $\mu_{\mathrm{A} 1 \mathrm{~B} 2}=\mu_{\mathrm{A} 2 \mathrm{~B} 2}$, tidak berhasil ditolak, dengan demikian rata-rata hasil belajar mahasiswa yang memiliki minat rendah dan diajar dengan model pembelajaran langsung tidak lebih baik dibandingkan dengan mahasiswa yang diajar dengan model pembelajaran website, ditolak karena tidak signifikan. Artinya hipotesis yang diterima adalah sebaliknya, pada kelompok minat rendah yang diajar dengan model pembelajaran website lebih baik dari kelompok yang diajar dengan model pembelajaran langsung. Hal ini disebabkan karena minat belajar rendah memiliki pengaruh yang dominan terhadap hasil belajar, sehingga mahasiswa yang memiliki minat belajar rendah menghasilkan perbedaan yang tidak terlalu menonjol.

Keterkaitan dari konsep bahwa model pembelajaran berbasis website merupakan suatu kegiatan pembelajaran memanfaatkan media situs (website) yang bisa diakses melalui jaringan internet, di mana didalamnya terdapat langkahlangkah harus dijalani dalam proses pembelajaran, memberikan pengalaman terhadap anak diberikan guru dalam bentuk kegiatan yang mengubah tingkah laku anak menjadi lebih baik. Pembelajaran menggunakan media website menggunakan teknologi internet. Dalam penggunaan website dalam pembelajaran adalah salah satu strategi pembelajaran untuk mencapai 
suatu tujuan pembelajaran, yaitu menuju perubahan hasil belajar yang lebih baik.

Relevan dengan hasil penelitian yang dilakukan oleh Erfan Priyambodo, Antuni Wiyarsi, dan Rr. Lis Permana Sari (2018:108). Hasil penelitian Pengaruh Media Pembelajaran Interaktif Berbasis Website terhadap Motivasi Belajar Mahasiswa diperoleh hasil bahwa Pembelajaran dengan menggunakan media interaktif berbasis web berperan dalam meningkatkan ketertarikan mahasiswa dalam belajar dan meningkatkan motivasi belajar mahasiswa.

Hasil Penelitian Farin Triana dan Rochmawati (2014:4) Perbedaan Hasil Belajar Mahasiswa Pembelajaran yang Menggunakan dan Tanpa Menggunakan Media Berbasis Web MOODLE Pada Materi Mengelola Kartu Aktiva Tetap di XI AK SMK Negeri 10 Surabaya diperoleh hasil bahwa terdapat perbedaan yang signifikan antara hasil belajar mahasiswa yang menerapkan model pembelajaran langsung dengan menggunakan media berbasis web moodle dan yang menerapkan model pembelajaran langsung tanpa menggunakan media berbasis web moodle. Perbedaan yang signifikan tersebut menunjukkan bahwa penerapan model pembelajaran langsung dengan menggunakan media berbasis web moodle dapat mempengaruhi hasil belajar mahasiswa. Hasil belajar yang menerapkan model pembelajaran langsung dengan menggunakan media berbasis web moodle lebih baik daripada yang menerapkan model pembelajaran langsung tanpa menggunakan media berbasis web moodle.
Ada pun temuan dalam penelitian ini bahwa, minat belajar mempengaruhi hasil belajar, mahasiswa yang memiliki minat belajar tinggi lebih baik daripada mahasiswa yang memiliki belajar rendah.

Berdasarkan hasil analisis dalam penelitian ini, maka dapat dikemukakan beberapa implikasi sebagai berikut: (1) Berdasarkan hasil analisis dalam penelitian ini menunjukan bahwa, mahasiswa yang memiliki minat belajar tinggi akan lebih efektif belajar dengan model pembelajaran website dan mahasiswa yang mempunyai minat belajar rendah lebih efektif menggunakan model pembelajaran website dan model pembelajaran langsung. Artinya, secara umum kebijakan yang dapat dilaksanakan adalah pada mata kuliah statistik yang digunakan fokus pada hasil penelitian ini, yaitu penggunaan model pembelajaran website dengan tujuan agar proses dan hasil belajar menjadi lebih efektif, efesien dan tepat guna. (2) Penggunaan model pembelajaran website pada mata kuliah statistik, selain dapat membantu mahasiswa yang mengalami kesulitan belajar, memiliki keterbatasan, dapat berefek positif lainnya, yaitu mampu meminimalisir biaya misal ongkos datang ke kelas jika tempat perkuliahan jauh dengan tempat tinggal, dan waktu, misal berdiskusi dan bertanya kepada dosen diluar kelas tentang materi yang belum dimengerti maupun nilai ujian dan tidak dirugikan ketika dosen berhalangan hadir karena adanya tugas tambahan maupun sakit. (3) Penggunaan model pembelajaran website memacu mahasiswa 
belajar lebih mandiri, mencari sumber-sumber belajar selain dari dosen, misal dari internet melalui website, pembelajaran tidak berpusat kepada dosen melainkan berpusat kepada mahasiswa. (4 ) Penting bagi pendidik untuk mengetahui minat belajar pada dalam diri mahasiswa sejak awal, agar mampu memprediksi untuk menerapkan model pembelajaran yang mana tepat untuk diterapkan. Berdasarkan hasil analisis dalam penelitian ini tenaga pendidik statistik sebaiknya menerapkan model pembelajaran website pada kelompok mahasiswa.

\section{KESIMPULAN}

Data hasil penelitian ini dapat disimpulkan: (1) Hasil belajar mahasiswa yang diajar dengan model pembelajaran website lebih baik dari hasil belajar mahasiswa yang diajar dengan model pembelajaran langsung. (2) Terdapat interaksi antara model pembelajaran website dengan minat belajar terhadap hasil belajar mahasiswa. (3) Hasil belajar mahasiswa yang memiliki minat tinggi dan diajar dengan modep pembelajaran website lebih baik daripada hasil belajar mahasiswa yang diajar dengan model pembelajar langsung. (4) Hasil belajar mahasiswa yang memiliki minat rendah dan diajar dengan model pembelajaran langsung tidak lebih tinggi daripada hasil belajar mahasiswa yang diajar dengan model pembelajaran website.

Berdasarkan uraian diatas maka diperoleh kesimpulan secara umum yang merupakan bagian dari temuan dipenelitian ini, terdapat interaksi antara model pembelajaran website dan minat belajar, dengan demikian maka mahasiswa yang memiliki perbedaan minat memerlukan model pembelajaran yang berbeda. Dalam penelitian ini, mahasiswa yang memiliki minat tinggi lebih baik menggunakan model pembelajaran website, sedangkan mahasiswa yang cenderung memiliki minat belajar rendah lebih baik belajar dengan kedua model, yaitu menggunakan model pembelajaran website dan model pembelajaran langsung.

Berdasarkan kesimpulan dan impilkasi dalam penelitian ini, untuk memperoleh pembelajaran yang optimal sehingga dapat mempengaruhi hasil belajar mahasiswa, maka disarankan: (1) Tenaga pendidik perlu mempunyai informasi tentang minat belajar mahasiswa, maka pihak program studi dan universitas serta instansi tertentu yang terkait dengan mengukur kepribadian, psikologi, dan minat mahasiswa. (2) Tenaga pendidik perlu diberikan pengetahuan lebih lanjut berupa pembekalan dan pelatihan tentang model pembelajaran website dari berbagai sumber belajar dan implikasinya. (3) Kepada peneliti lain, penelitian ini membuktikan bahwa peningkatan belajar dapat dilakukan dengan pengimplementasian model pembelajaran yang tepat dengan didasarkan pada tingkat minat mahasiswa, tidak tertutup kemungkinan ada variabel lain yang berpengaruh, seperti latar belakang, kondisi lingkungan dan keluarga mahasiswa, keaktifan mahasiswa dalam perkuliahan. Contoh variabel tersebut tidak 
dilaksanakan oleh peneliti, oleh karena itu disaranka agar peneliti lain melakukan penelitian lanjutan dengan variabel-variabel ataupun mata kuliah yang lain yang diduga dapat mempengaruhi hasil belajar mahasiswa pada program studi Teknik Mesin. (4) Peneliti lain dapat membuat lanjutan penelitian suatu produk berdasarkan penelitian ini dengan mengembangkan suatu model pembelajaran website terhadap hasil belajar mata kuliah yang lain ataupun dimata kuliah lainnya, misalnya mata kuliah Landasan Teknologi pendidikan, Metode Penelitian, filsafat ilmu, matematika, fisika dan lainnya.

\section{DAFTAR PUSTAKA}

Undang-Undang Nomor 20 Tahun 2003 tentang Sistem Pendidikan Nasional, Pasal 31, ayat 1, 2 dan 3.

Musfiqon. (2012). Pengembangan Media dan Sumber Pembelajaran, Jakarta: PT. Prestasi Pustakaraya.

Muhibbin Syah. (1997). Psikologi pendidikan dengan pendekatan bani, Bandung: Remaja Rosdakarya.

Iqbal Hasan, (2009). Analisis Data Penelitian dengan Statistik, Jakarta: PT Bumi Aksara.

Sudjana. (2005). Metoda Statistika, Bandung: PT. Tarsito Bandung.

Anas Sudijono. (2012). Statistik Pendidikan,
Jakarta: PT RajaGrafindo Persada.

Asep Jihad. Abdul haris. (2012). Evaluasi Pembelajaran, Yogyakarta: Multi Pressindo.

Trianto Ibnu Badar Al-Tabany. (2014). Mendesain Model Pembelajaran Inovatif, Progresif, dan Konstektual, Jakarta: Kencana.

Abdul Aziz Wahab. (2008) Metode dan model-model mengajar, Bandung: Alfabeta.

HA. Mooduto, Rahmat Hidayat, Yuhefizar. (2006). Pelatihan Web Design, Bogor: Politeknik Negeri Padang.

Tahmat Hidayat. (2010) Cara Praktis Membangun Website Gratis, Jakarta: PT Elex Media Komputindo.

Trianto. (2012). Mendesain Model Pembelajaran Inovatif-Progresif, Konsep, Landasa, dan Implementasinya Pada Kurikulum Tingkat Satuan Pendidikan (KTSP), Jakarta: Kencana.

Arthur S. Jones. (1968). Principles of Guide, New york: Mc. Graw-Hill Book Company, Inc.

Henry E Garret. (1965). Testing for Teacher, New York American Book Company. 
Djaali. (2008). Psikologi Pendidikan, Jakarta: Bumi Aksara.

H.H. Taringan. (1989). Membaca dalam Kehidupan Individu, Bandung: Angkasa.

C.E. Skinner. (1958). Essential of Fudamental Psychology, New York: Practice Hall, Inc England, Cliff.

Lester D. Crow \& Alice Crow. (1989). Educational Psychology a.b. Abd. Rahman Abror, Yogyakarta: Nur Cahaya.

Sabri, Alisuf. (2007). Psikologi Pendidikan. Jakarta: Pedoman Ilmu Jaya.

Andin Sefrina. (2013). Deteksi Minat Bakat Anak, Yogyakarta: Media Pressindo.
M. Ngalim Purwanto. (2007). Psikologi Pendidikan, Bandung: PT Remaja Rosdakarya.

Erfan Priyambodo, Antuni Wiyarsi, dan Rr. Lis Permana sari. (2012). Pengaruh Media Pembelajaran Interaktif Berbasis Web Terhadap Motivasi Belajar Mahasiswa, Jurnal Kependidikan, Vol. 42(2).

Farin Triana dan Rochmawati. (2014). Perbedaan Hasil Belajar Siswa pembelajaran yang menggunakan dan Tanpa Menggunakan Media Berbasis Web Moodle Pada Materi Mengelola Kartu Aktiva Tetap di XI AK SMK Negeri 10 Surabaya, Jurnal Pendidikan Akuntansi (JPAK), Vol. 2(2). 